\title{
POLÍTICAS AMBIENTAIS COMPARADAS ENTRE PAÍSES DO SUL: pressão antrópica em Áreas de Proteção Ambiental Urbanas*
}

\author{
Prof $^{\mathrm{a}}$. Dra ${ }^{\mathrm{a}}$.Neli Aparecida de Mello-Théry \\ Instituto de Estudos Avançados, Programas de pós-graduação em Geografia Humana USP \\ Av. Arlindo Béttio, 1000. Ermelino Matarazzo. CEP: 03828-000 - São Paulo (SP), Brasil
} Tel. (+55 11) 30911029 - namello@usp.br

Prof. Dr. Frédéric Landy frederic.landy@wanadoo.fr

Prof $^{\mathrm{a}}$. Dra ${ }^{\mathrm{a}}$. Marie-Héléne Zérah zerah@ird.fr

\section{RESUMO}

Este texto visa comparar as políticas públicas espaciais e suas ações voltadas para as áreas de proteção ambiental urbana em duas metrópoles, São Paulo e Mumbai (Índia), tomando-se como elemento organizador a presença de florestas urbanas protegidas sob a forma de unidades de conservação (categoria II, da IUCN). Segundo Sartori (1981) ressaltar semelhanças e diferenças constitui uma forma simples, eficaz e interessante da política pública comparada, enfatizando que estes elementos podem fazer parte do discurso local. Com esta ênfase, procura-se analisar o Parque Nacional Sanjay Gandhi e o Parque Estadual da Cantareira e destacar os fatores escolhidos para a comparação, seja a transformação da floresta em área de conservação urbana ou a territorialização dos conflitos entre usos ecológico e urbano. Conclui-se o artigo com a análise das estratégias de políticas públicas.

Palavras-chave: Proteção das áreas naturais, pressão antrópica, Mumbai, São Paulo, Sanjay Ghandi National Park, Parque Estadual da Cantareira.

\section{ABSTRACT}

This paper aims to compare the spatial policies and their actions towards the urban areas of environmental protection in two cities, São Paulo (Brazil) and Mumbai (India), taking as an organizing element the presence of urban forests in the form of protected conservation areas (Category II , IUCN). Sartori (1981) highlighting similarities and differences is a simple, effective and interesting method to comparative public policies, emphasizing that these elements may be part of local discourse. With this emphasis, we attempt to analyze the Sanjay Gandhi National Park and Cantareira State Park and highlight the factors chosen for comparison: the conversion of forest to urban conservation areas and territorial conflicts between environmental and urban uses. We conclude the article with the analysis of policy strategies.

Key words: Protection of natural areas, anthropic pressure, Mumbai, São Paulo, Sanjay Gandhi National Park, Cantareira State Park.

\section{RÉSUMÉ}

Cet article vise à comparer les politiques spatiales et leurs actions envers les zones de protection de l'environnement dans deux villes, São Paulo (Brésil) et Mumbai (Inde), considérant la présence de forêts urbaines protégées comme aires de conservation (Catégorie II , l'UICN). Sartori (1981) souligne que rechercher les similitudes et les différences est une manière simple, efficace et intéressant d'élaborer des politiques publiques comparés, en soulignant que ces éléments peuvent faire partie du discours local. Suivant cette approche, nous analyserons le Parc National Sanjay Gandhi et le Parc d'État de la Cantareira et mettrons en évidence les facteurs retenus pour la comparaison : la conversion des forêts en zone de conservation urbaine et les conflits territoriaux entre usages environnementaux et urbains. Nous concluons l'article par l'analyse des stratégies politiques.

Motss-clé: Aires de protection environnementale, pression anthropique, Mumbai, São Paulo, Parc National Sanjay Gandhi, Parc de l'État de la Cantareira.

\section{INTRODUÇÃO}

A dimensão comparativa permite passar do singular ao universal por meio de uma abordagem generalizadora. Para tanto tem que identificar seus conceitos basilares. Neste trabalho, para analisar os processos de implantação das políticas e programas urbanos e seus instrumentos, os conceitos de florestas urbanas e políticas territoriais foram estabelecidos como parte do referencial teórico.

(*) Este artigo resulta da pesquisa "Social Exclusion, Territoires et politiques urbaines", financiado com recursos da Agence National de La Recherche (França), desenvolvida entre os anos de 2007 e 2010. 
Trata-se de uma maneira de contribuir para uma reflexão sobre as condições de pressão antrópica sobre as áreas protegidas.

Steinberger (2003:45) ressalta que as ações públicas ocorrem no espaço, por isso, servindo-se de uma abordagem relacional entre as políticas, insere o espaço não pulverizado nas políticas públicas espaciais... razão pela qual, considera-o como o berço do território e do ambiente. Para ela, a análise ambiental pressupõe uma análise territorial, sendo o uso do território o objeto da analise social. As cinco noções (ambiental, territorial, regional, urbano e rural) constituem o espaço relacional e, embora possa haver uma política ambiental, uma territorial, uma urbana e rural, devem ser formuladas em termos nacionais e, acrescento, integrado.

Outro elemento fundamental para a abordagem comparativa foi a classificação internacional das duas unidades de conservação: o Parque Nacional Sanjay Gandhi (SGNP) e o Parque Estadual da Cantareira (PEC) são inscritos na mesma categoria estabelecida pela IUCN (União Internacional de Conservação da Natureza) e, portanto, dispõem de diretrizes de políticas públicas semelhantes. Assim, procurou-se justapor dados para a avaliação das políticas relacionadas com a conservação ambiental, destacando-se as inter-relações entre a pressão urbana, o meio ambiente urbano e o espaço periurbano. A questão colocada é como conciliar medidas governamentais, sociais e ecológicas, com objetivos de proteger reservas de biodiversidade necessárias ao metabolismo urbano, marcado por fortes pressões decorrentes do crescimento urbano, caracterizado, sobretudo por habitações ilegais (invasões, favelas).

Considerou-se, portanto, que a evolução destas políticas públicas induz, dentro do espaço urbano, transformações sociais comparáveis a outras regiões cujos processos se assemelham. A comparação das políticas adotadas nas duas cidades em relação aos parques pode contribuir à compreensão dos mecanismos de exclusão e de pressão sobre as áreas protegidas.

\section{APRESENTANDO O CRESCIMENTO URBANO DE MUMBAI E SÃO PAULO}

A história recente das duas cidades esta ligada ao forte poder de atração de mão de obra, para a agricultura, para a indústria e depois para serviços terciários.

A Índia possui a segunda população urbana do mundo, com 285 milhões, embora a população rural seja dominante. Enquanto no Brasil a urbanização atinge 84,2\%, na India são apenas 27,8\% da população total (censo de 2001). Quatro dos dez maiores aglomerados urbanos mundiais - Mumbai, Delhi, Calcutá e Chennai - ilustram o paradoxo indiano, pois, apesar de a taxa de crescimento urbano permanecer baixa (cerca de 3\%), a população da região metropolitana de Mumbai ultrapassou os 14 milhões de habitantes em 2009.

A área ocupada por Bombaim foi concedida ao Império Britânico em 1662; arrendada à Companhia das Índias Orientais em 1668 e em meados do século XIX tornou-se o principal centro de comércio para a Inglaterra. Com o rápido crescimento ocorreu o processo de polderização das 7 (sete) ilhas pantanosas, nas quais a cidade foi construída. A partir de uma plataforma logística e financeira para os fluxos de mercadorias, Bombaim se tornou uma cidade industrial, principalmente para o algodão. Grandes áreas foram dedicadas às fábricas de algodão, atraindo milhares de trabalhadores de toda a Índia e transformando a economia da cidade e da população. A cidade trocou o seu nome para Mumbai somente em 1995.

No período pós-independência (1947), a capital do estado de Maharasthra era o centro de modernas indústrias e do comércio nacional e internacional. Com o fluxo de imigrantes a cidade cresceu de forma exponencial e incorporou os subúrbios ao norte. Esse passado de glória não impediu o declínio assustador de seu desempenho econômico: industrial nos anos 1980, seguido pela liberalização econômica na década de 1990. Mumbai entrou no processo de globalização com o predomínio de atividades terciárias, empurrando a indústria para lugares menos "nobres", a exemplo da petroquímica localizada principalmente em torno de Navi Mumbai, enquanto o "Maximum City" continua a ser a capital financeira e comercial da Índia. O resultado espacial deste processo se expressa nas favelas, onde vive de 54,5\% dos habitantes na Grande Mumbai. 
A história da cidade revela a expansão urbana do sul para o norte, em três escalas de tempo e lugar: a) o centro da cidade localiza-se na ilha, cujo crescimento populacional foi significativo até 1950, possui uma administração própria, a Bombaim Municipal Corporation (BMC, criada em 1982); b) a Grande Mumbai, criada em 1950 e que em 1957 teve sua área expandida para 438 km2, aumentando em 12 vezes sua população. : Estes suburbios tornaram-se, apos 1981, maior distrito do estado de Maharasthra em termos populacionais. O BMC transformou-se em Corporação Municipal da Grande Mumbai (MCGM); e, finalmente em região metropolitana de Mumbai, criada em 1975, para incluir áreas mais interioranas devido ao rápido crescimento (Thane Municipal Corporation, Kalyan MC, Virar-Bhayandar, Bhiwandi, e a "nova cidade planejada", Navi Mumbai). A área total desta região metropolitana é de $4.355 \mathrm{~km}^{2}$.

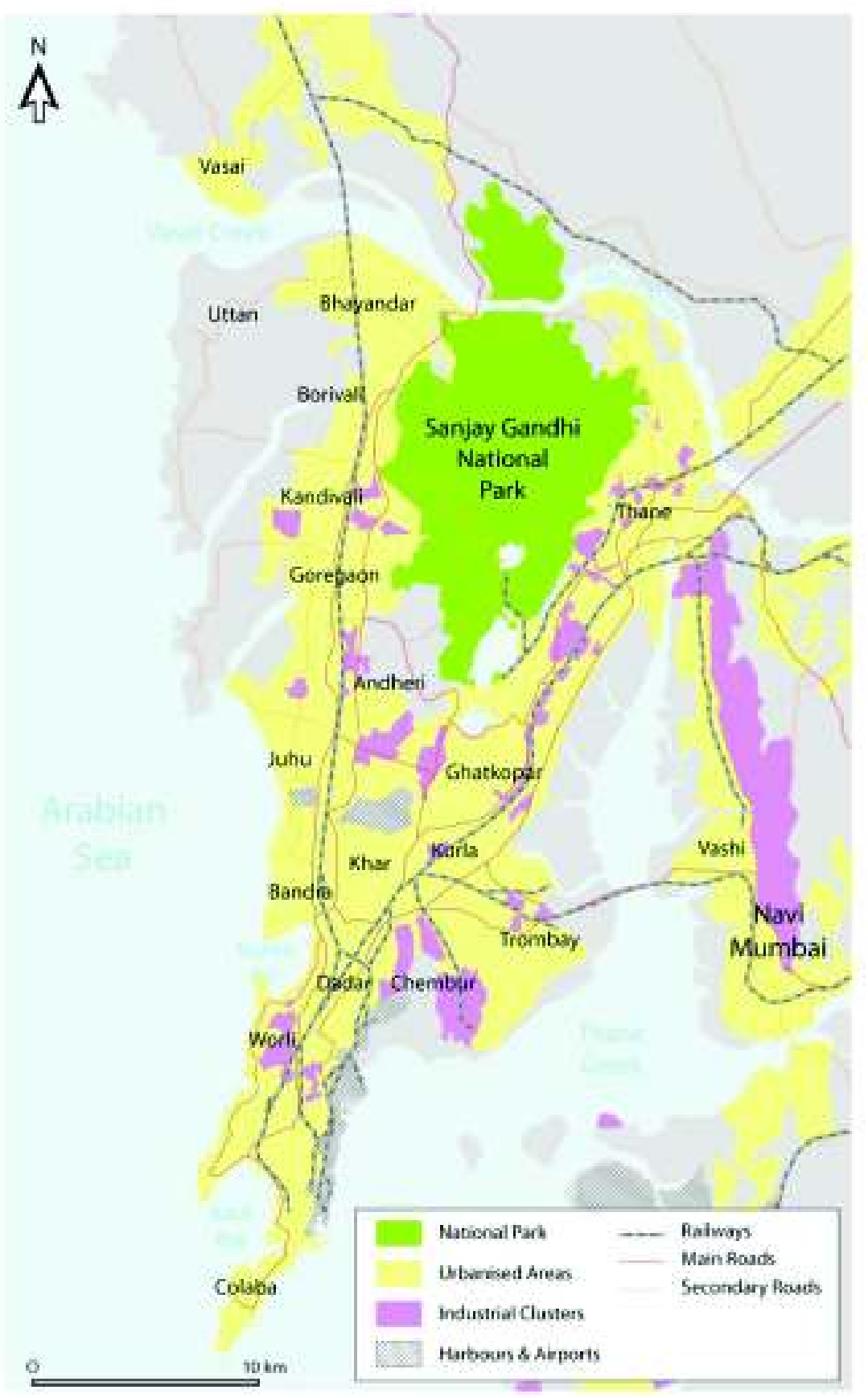

Figura 1 - Mapa de Localização do Sanjay Gandhi National Park em Mumbai 
A escassez de terra para expansão urbana ao sul e as restrições geofísicas do sítio explicam o impressionante crescimento demográfico dos subúrbios, o que revela tanto a forte urbanização como os processos de densificação do trabalho em Mumbai. A expansão urbana transformou o Parque em um enclave.

Já São Paulo, a maior metrópole brasileira, tem sua história ligada fundamentalmente à expansão da cultura cafeeira no Brasil (até a queda da Bolsa de 1929), substituída pela indústria (anos 1960 a 1990), sendo atualmente uma cidade diversificada de serviços, dos mais simples aos mais sofisticados. De vila à metrópole: de pequena cidade no primeiro censo brasileiro (1872) para a capital econômica brasileira em menos de um século. O deslocamento dos centros econômicos de São Paulo, em 4 momentos importantes corresponde às mudanças da economia da cidade: a) De seu primeiro centro urbano (Praça da Sé, Pátio do Colégio) ligado ao nascimento da cidade e à produção cafeeira à b) mudança do eixo econômico do período industrial (Av. Paulista, sede da Federação das Indústrias do Estado) aos c) novos centros econômicos (Av. Berrini, Av. das Nações) das empresas de tecnologia, símbolo da cidade globalizada, d) a metrópole formada por 34 municípios conurbados entre si. Não há administração metropolitana, apenas um órgão técnico (Emplasa - Empresa paulista de planejamento metropolitano S.A.) com atividades de apoio ao planejamento, programação, organização, coordenação e execução dos serviços comuns de interesse metropolitano.

São Paulo é definida como metrópole, juntamente com outras oito regiões, no início dos anos 1970 pela Lei Complementar Federal no 14/1973. À época, já exercia influência e nutria um intenso processo de conurbação e dependência com os municípios vizinhos, conforme pode ser identificado pela imagem de satélite abaixo. A indústria nascente, foco das atividades econômicas do período, demandava mão de obra e aumentou a atração por empregos. Desde a década de 1940 chegaram migrantes de todo o país. A cidade ainda tinha condições de prover habitação à maioria dos trabalhadores, pois à época existiam apenas 4 favelas (Saraiva e Marques, 2005). A partir daí até os anos 1960, o padrão de urbanização foi disperso, pouco denso e precário, formando uma mancha urbana desarticulada, cujo centro cresceu $171 \%$ e a periferia $364 \%$, composto essencialmente de população de baixa renda (Biderman, Meyer e Grostein, 2004). As favelas representam parte dessa urbanização precária. Em 1973, segundo Taschner (2000, in Saraiva e Marques, 2005) a favelas alojavam cerca de 1\% (70 mil habitantes ) da população do município de São Paulo.

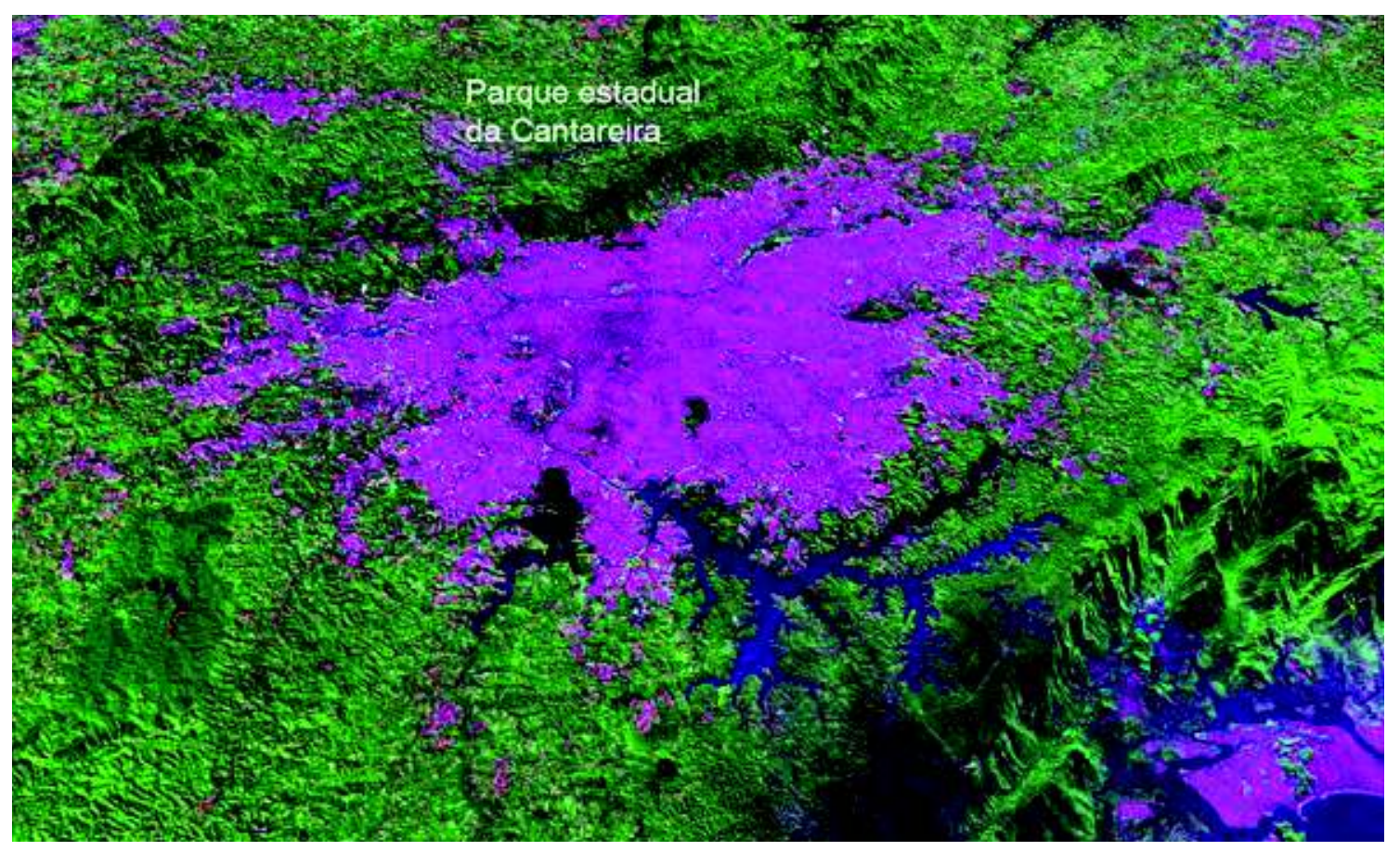

Figura 2 - Parque Estadual da Cantareira 
Evidentemente a instalação da indústria sem nenhum controle ambiental é propicia ao aparecimento da poluição atmosférica. Dois anos após a criação das regiões metropolitanas instaura-se o Decreto Lei 1.413, de 14 de agosto de 1975, sobre o controle da poluição do meio ambiente provocada por atividades industriais. Em 1980, com a lei 6803/80, foi estabelecido o zoneamento em áreas críticas de poluição, definindo-se as primeiras restrições legais ao uso do solo metropolitano.

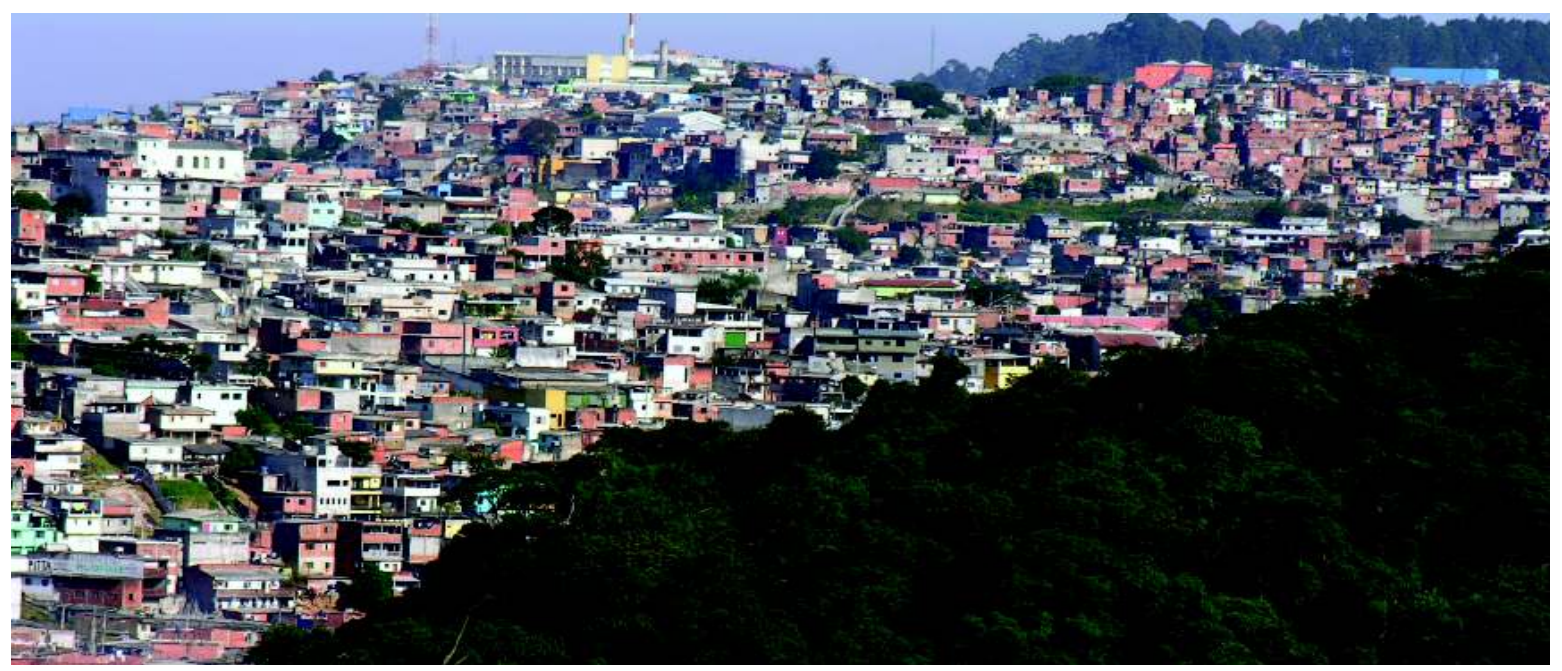

Figura 3 - Crescimento dos bairros nos limites do Parque Estadual da Cantareira. Foto Hervé Théry, 2007.

Porém, em 1987, a população em favelas já correspondia a 9\% da população urbana (812 mil) , ocupando áreas impróprias e interditadas, como as áreas de preservação permanente. $\mathrm{O}$ crescimento dessa população é três vezes maior que o do município e tornou-se uma constante na periferia paulistana. Na zona norte, o crescimento atingiu uma taxa de 3\% ao ano entre 1991 e 2000 (Biderman, Meyer e Grostein, 2004) provocando uma contínua ocupação das áreas de preservação ambiental da Mata Atlântica e de proteção de mananciais. Fato semelhante ocorre nas proximidades dos reservatórios de Guarapiranga e de Billings, ao sul do município de São Paulo. Os problemas e os riscos ambientais são numerosos.

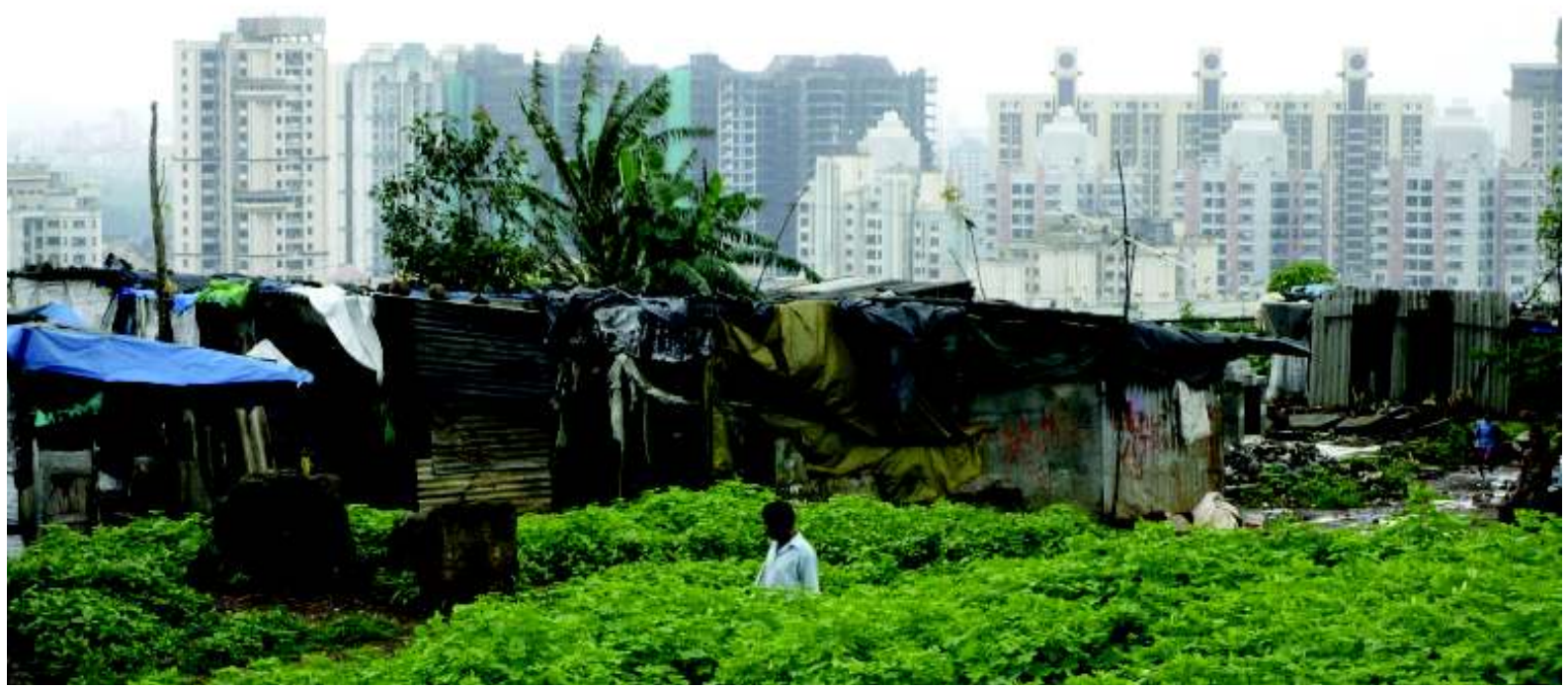

Figura 4 - Crescimento de Mumbai em direção ao Sanjay Gandhi National Park. Foto de Frédéric Landy. 2009. . 


\section{TRANSFORMANDO AS FLORESTAS URBANAS}

A transformação de florestas urbanas em áreas de conservação (categoria II da IUCN) no seio de grandes metrópoles é uma estratégia para tratar de aspectos da qualidade, da legislação ambiental e sua relação com o uso do solo para a habitação.

Estas florestas, localizadas ao norte das duas regiões metropolitanas, são pressionadas pelo uso habitacional que transforma as paisagens naturais: no SGNP, pelas maiores taxas de crescimento populacional nas adjacências, e no PEC, pela expansão dos conjuntos habitacionais de baixa renda ou condomínios fechados (classe média e alta). Nos argumentos de venda em empreendimentos imobiliários de alto padrão, os dois parques são vistos como símbolos da qualidade ambiental e do contato com a natureza. Além disso, agrega-se o desconhecimento de estratégias da política habitacional pela política ambiental e vice-versa, sendo que as escolhas de locais para as populações de baixa renda têm representado um alto ônus ao ambiente local. Em São Paulo, as estradas vicinais e o Rodoanel também produzem impactos semelhantes e, aos poucos, indicam o enclausuramento do PEC na mancha urbana.

Os dois principais eixos de crescimento urbano, em direção ao norte e em direção ao nordeste ao longo das duas estradas de ferro, cercaram o Parque Sanjay Ghandi como um enclave: uma ilha de floresta no meio da urbanização. Além da estrada de ferro, a rodovia Ghodbandar também é um forte vetor, com habitações, resorts, atividades industriais e comerciais cortam a área florestal.

\section{A relevância do Sanjay Gandhi National Park e do Parque Cantareira}

Estudiosos têm defendido a necessidade de uma avaliação econômica dos serviços ambientais fornecidos pelos Parques, pois, como um enorme espaço natural, a floresta e a biomassa tanto o Sanjay Gandhi como o da Cantareira, atuam como um pulmão para a limpeza das poluições industriais e da frota de veículos para os habitantes.

Os serviços ambientais prestados por estas florestas urbanas incluem a amenização do clima (purificando o ar e resfriando as temperaturas), a redução da poluição atmosférica e a conservação da biodiversidade local. Os Parques funcionam como espaço regulador para a manutenção do equilíbrio e das qualidades ambientais e fornecedores de água e regularizadoras da vazão dos rios e contribuem para a saúde pública de suas Regiões Metropolitanas. Na atualidade, maior relevância tem sido dada à necessidade de conhecer e conservar a diversidade biológica existente, já tendo sido identificado espécies ameaçadas em ambos.

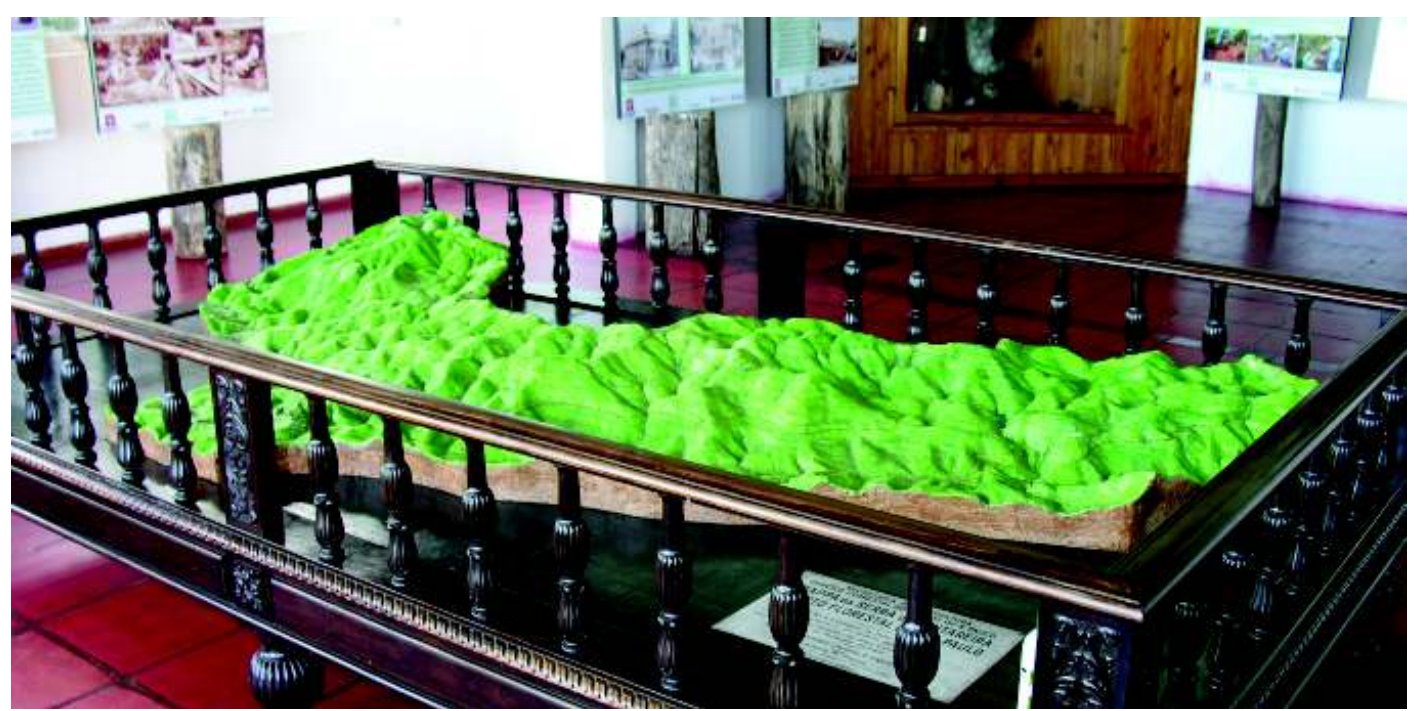

Figura 5 - A maquete do Parque Estadual da Cantareira permite visualizar seu relevo ondulado. Foto de Frédéric Landy. 2009. 
Apesar da importância desta função, estas áreas simbolizam a pressão antrópica, a exclusão social e as difíceis relações entre políticas públicas.

Quanto ao fornecimento de água os dois Parques possuem também semelhanças: no Sanjay Gandhi, os lagos de Tulsi e Vihar, cujas bacias hidrográficas encontram-se dentro dos limites do parque, fornece entre 3 a 5\% de água potável para Mumbai. A bacia Tulsi (localizado na zona central do parque) é bem protegida, enquanto a bacia de Vihar bacia (localizada na extremidade sul) desmatada e propensa a erosão do solo. O Parque da Cantareira faz parte do Sistema Cantareira, que durante anos serviu para o abastecimento de água para São Paulo por meio das represas do Engordador e Barrocada, atualmente desativas, além da Cabuçu, em processo de recuperação.

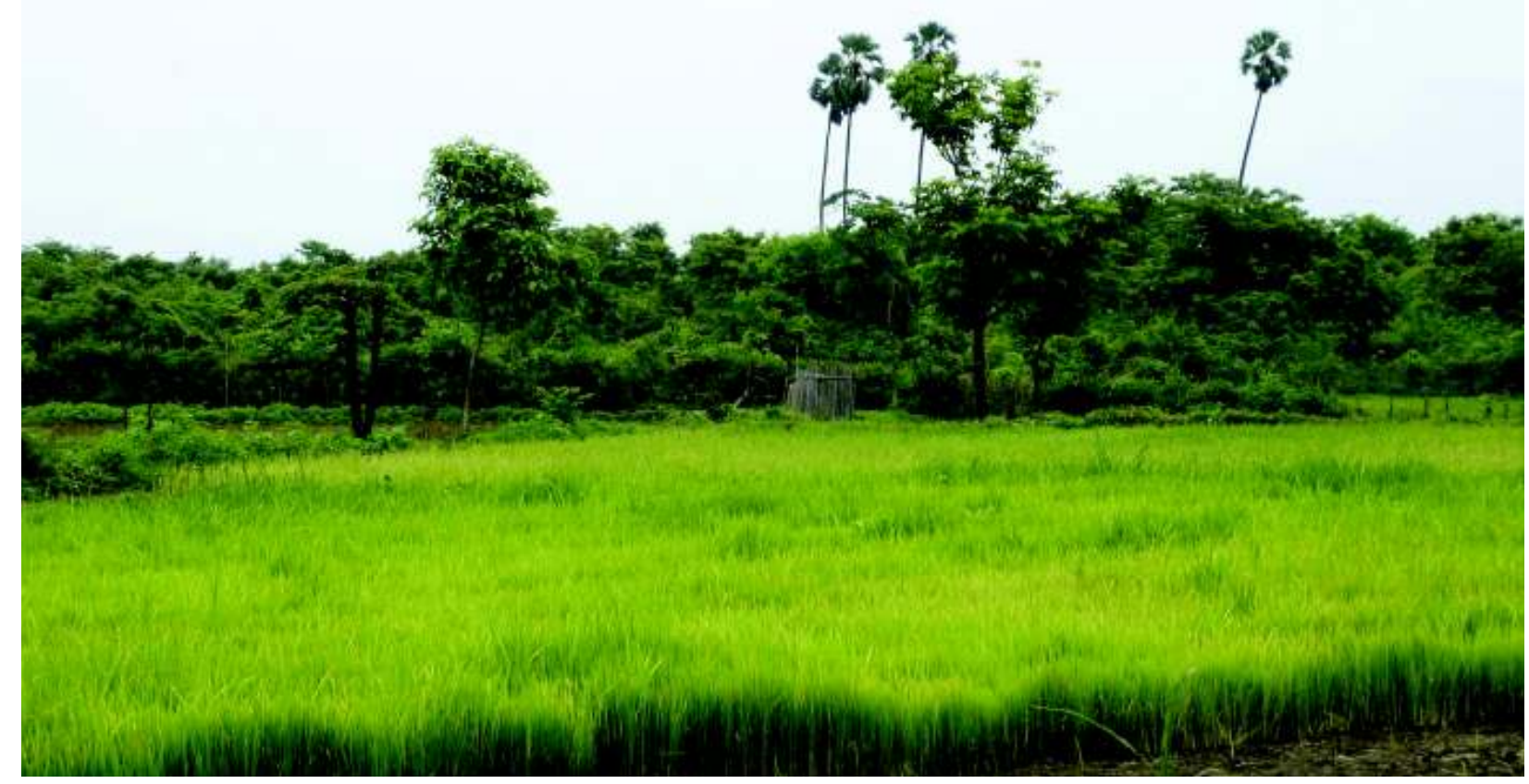

Figura 6 - Areas inundaveis no interior do Sanjay Gandhi National Park; Foto Frederic Landy, 2008 Foto Frederic Landy, 2008.

Os dois Parques possuem características geológicas similares: no SGNP, o maior patamar de basalto do Ecocene do Cretáceo Superior (Bon, 2008) e rochas metassedimentares e granitos intrusivos. A Pedra Grande é o melhor exemplo da presença de rochas graníticas, no PEC. Localizado na Ecorregião Floresta Malabar, o SGNP inclui cinco grandes grupos de florestas, sendo a principal delas a decídua úmida do sul. A vegetação do Parque está longe de ser "natural", pois a silvicultura comercial à época do domínio britânico, seguido pela silvicultura científica que ocorreu até 1972 são de origem secundária. As espécies de árvores dominantes são indicadores de que foram introduzidas. Essas plantações podem ter tido significado político, o de "marcar o seu território", a fim de evitar a invasão. «Durante um período de duas semanas, em 2003, voluntários plantaram, com sucesso, cinco sementes lakh em terrenos valorizados que foram reclamados por mais de 50 000 invasores ilegais e 3.000 estabelecimentos comerciais clandestinos na área", disse Digambar Dahibaokar, guarda-florestal. "Cobrir a área com plantas impedem que ele seja usurpado no futuro. Ele também irá garantir que os esforços do Dr. A.R. Bharati, ex vice-diretor do Parque Nacional para expulsar os invasores, com respaldo político, não foram em "vão".

Observações de campo confirmam que a cobertura florestal varia de densa floresta para áreas abertas dentro do SGNP. Paranjpye (1997) atribuiu à degradação ecológica a dois fatores principais: a exploração comercial dos recursos florestais e o impacto das dificuldades econômicas das comunidades que extraem recursos para sua própria sobrevivência. Assim, os planos de manejo florestal até 1972 contribuíram para a sua degradação ecológica. 


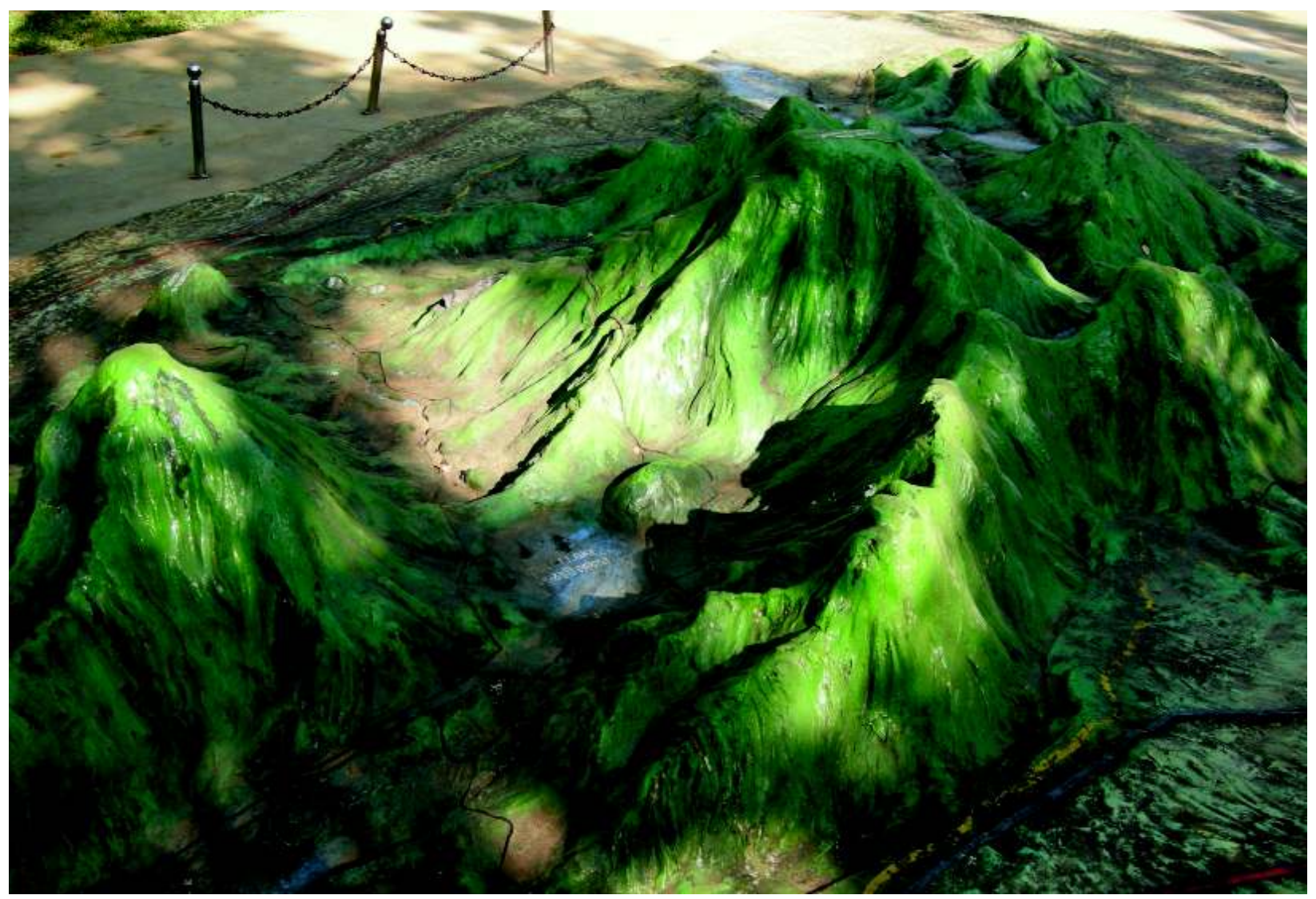

Figura 7 - A maquete do Sanjay Gandhi National Park permite identificar o relevo montanhoso. Foto Hervé Théry, 2009.

No que diz respeito às mudanças ecológicas e aos níveis de biodiversidade, a situação dos dois Parques também é semelhante. Há falta de dados de referência como uma das principais dificuldades. Para o Sanjay Gandhi há apenas três fontes principais disponíveis: a) a avaliação ambiental (Paranipve, 1997) baseada em observações, entrevistas e pesquisas de campo com foco na diversidade de espécies, diversidade genética da flora e fauna; b) inventários de fauna e flora da Sociedade de História Natural de Bombaim (BNHS) e c) censo de panteras realizado pelo Departamento Florestal $(1994,2005)$. Estes estudos revelam importante diversidade biológica, animal e vegetal . Degradação do habitat, assentamentos humanos e movimentos dentro e perto do Parque e a conseqüente diminuição do número de animais. Várias espécies, como antílopes de quatro chifres, nilgar sambar, e que haviam se tornado extintas têm sido reintroduzida com sucesso pelo Departamento Florestal que promove também a prisão, enjaulamento e liberação de leopardos em outros lugares. Para cumprir a ordem da High Court de 1967, várias salas de controle foram erigidas objetivando acompanhar os leopardos que se deslocam para fora, e uma parede esta em construção para impedir que os leopardos e moradores de favelas se moverem para dentro e fora do SGNP. Foram registrados 118 ataques de leopardos contra mulheres e crianças em torno do SGNP e a 73 mortes entre 1998 e 2006. Esta situação ambiental transforma o SGNP em um "bem comum" para uma complexa rede de interessados em diferentes escalas.

Quanto ao Parque da Cantareira que é uma das áreas core da Reserva da Biosfera do Cinturão Verde da Cidade de São Paulo (RBCV). Este "coração" da Reserva tem como característica principal ser uma das poucas unidades de conservação (categoria II) situada em perímetro urbano. 


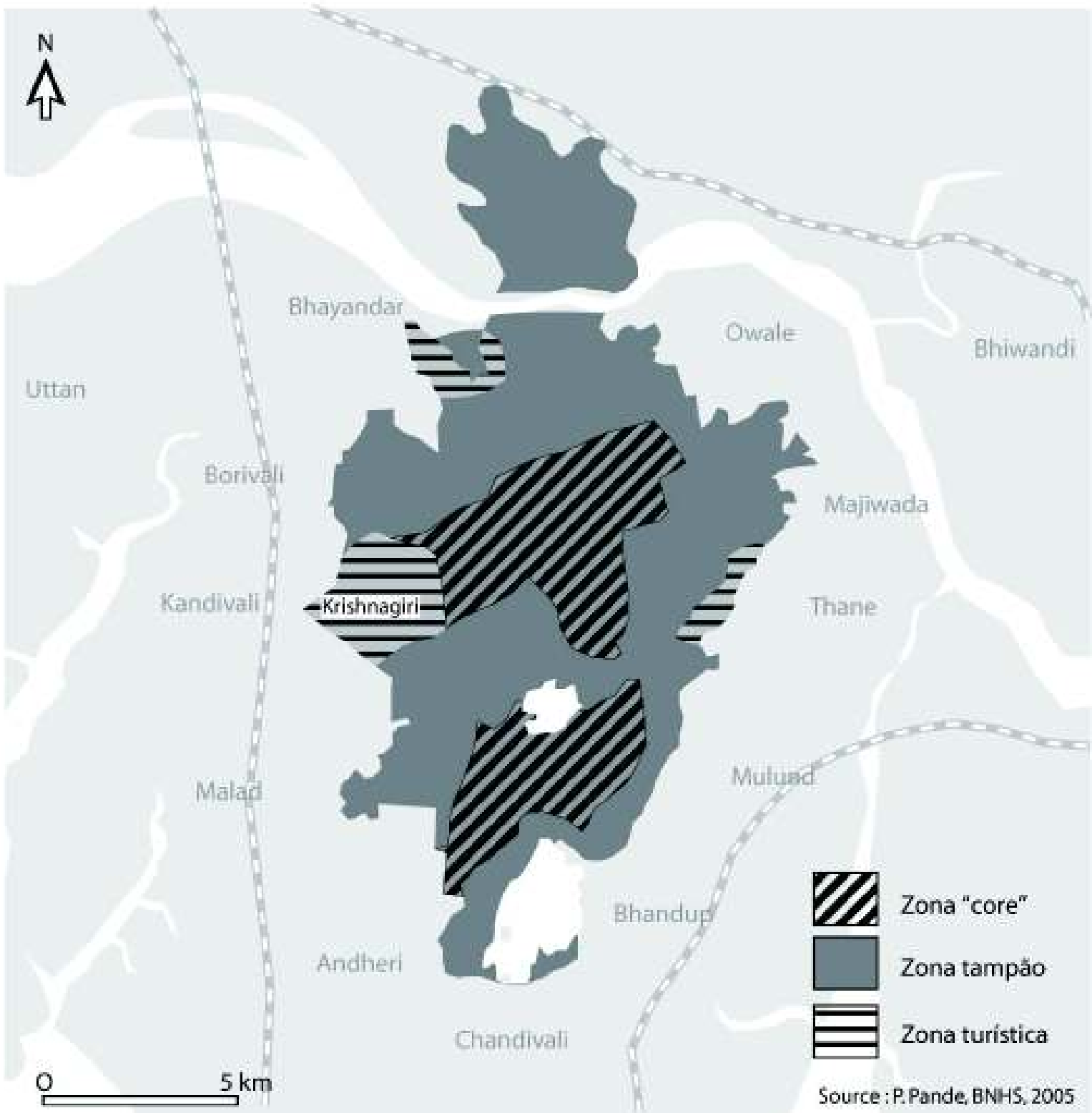

Figura 8 - Mapa de distribuição das zonas internas do Parque Nacional Sanjay Gandhi

A relevância do Parque Estadual da Cantareira pode ser identificada pelas diferenciadas funções que já exerceu como a produção de verduras e frutas para o abastecimento de São Paulo. Assumiu também o papel de proteção das numerosas nascentes para o abastecimento de água potável constituindo, a partir de 1980, o sistema Cantareira, para assegurar o fornecimento de água para a cidade de São Paulo. Como a área já tinha sido explorada desde o final do século XIX com fazendas de café, chá e cana de açúcar, o governo do Estado fez a desapropriação das fazendas visando recuperar a mata e garantir a manutenção das nascentes e córregos existentes na Serra do mesmo nome. Para garantir a propriedade do Parque, o Estado adquiriu essas terras e investiu na regeneração da vegetação. Novos assentamentos foram instalados na região nas décadas de 1950 à de 1980, com a cidade se aproximando da Serra da Cantareira e dos limites do Parque, sem respeitar as zonas de amortecimento limítrofes. Segundo Silva e Grostein [200_] esse processo se intensificou na década de 1990 seja com a consolidação de áreas já ocupadas ou a abertura de novos loteamentos, novos edifícios e com a revalorização de áreas de ocupação antiga. Esse processo ocorre no mesmo período em que o Brasil ratifica a Convenção de Conservação da Biodiversidade e começa a estabelecer uma política específica para a conservação dos remanescentes da Serra da Cantareira . 


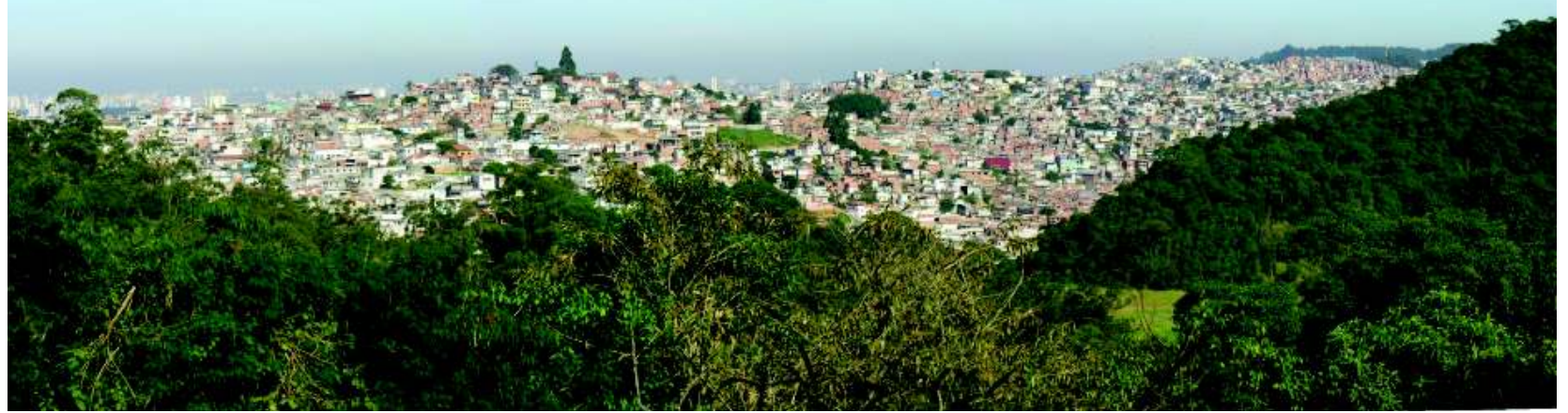

Figura 9 - Vista da Pedra Grande, no Parque Estadual da Cantareira em direção à Vista Alegre.

Foto Hervé Théry, 2007.

Um parque cercado por uma cidade em expansão... ou um parque que cresceu em direção à cidade?

Em uma perspectiva histórica é possível considerar que as cidades de Mumbai e São Paulo se aproximaram dos Parques. Em Mumbai, porém, o Parque também cresceu em direção à cidade. As florestas que hoje são urbanas, um dia estiveram muito longe das cidades. As cidades chegaram até elas, transformando-as em lugares de ocupação ilegal, precários, local dos excluídos.

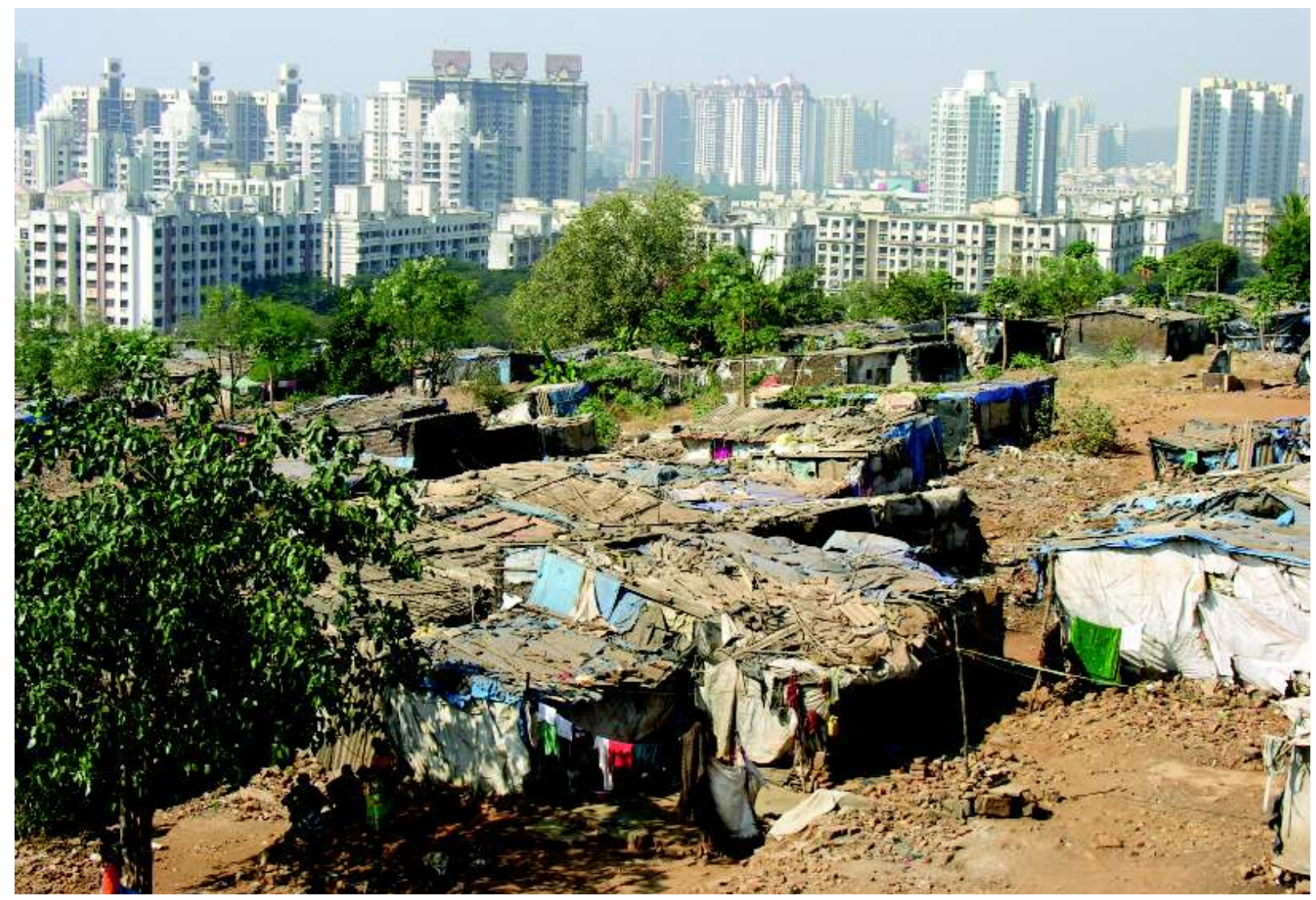

Figura 10 - Regiao de Krantinagar. Segundo a administraçao, as choupanas estao no Sanjay Gandhi National Park. Foto Frédéric Landy, 2009.

A extensão permanente da área protegida tem "invadido" áreas rurais adjacentes ao parque. O núcleo do parque sempre teve um estatuto específico, desde a era Maratha (Paranjpye, 1997), devido à sua altitude (ponto culminante de $466 \mathrm{~m}$ ) e ao seu relevo (declives acentuados). Mas os limites atuais do SGNP resultam de um processo histórico de concentração de vários setores florestais e terrenos agrícolas: o Parque Krishnagiri tinha apenas $21 \mathrm{~km}^{2}$, quando foi criado, em 1950. 
Atualmente tem $103 \mathrm{~km}^{2}$. Muitos trechos da atual área protegida foram propriedade privada até um passado recente, por exemplo, a vila Chena foi explorada por inamdors sem nenhuma regulação até 1956. O parque "juntou terras e posses" (Paranipye, 1997), tendo sido multiplicado por cinco entre 1967 e 1982, conforme pode ser visualizado na figura 11.

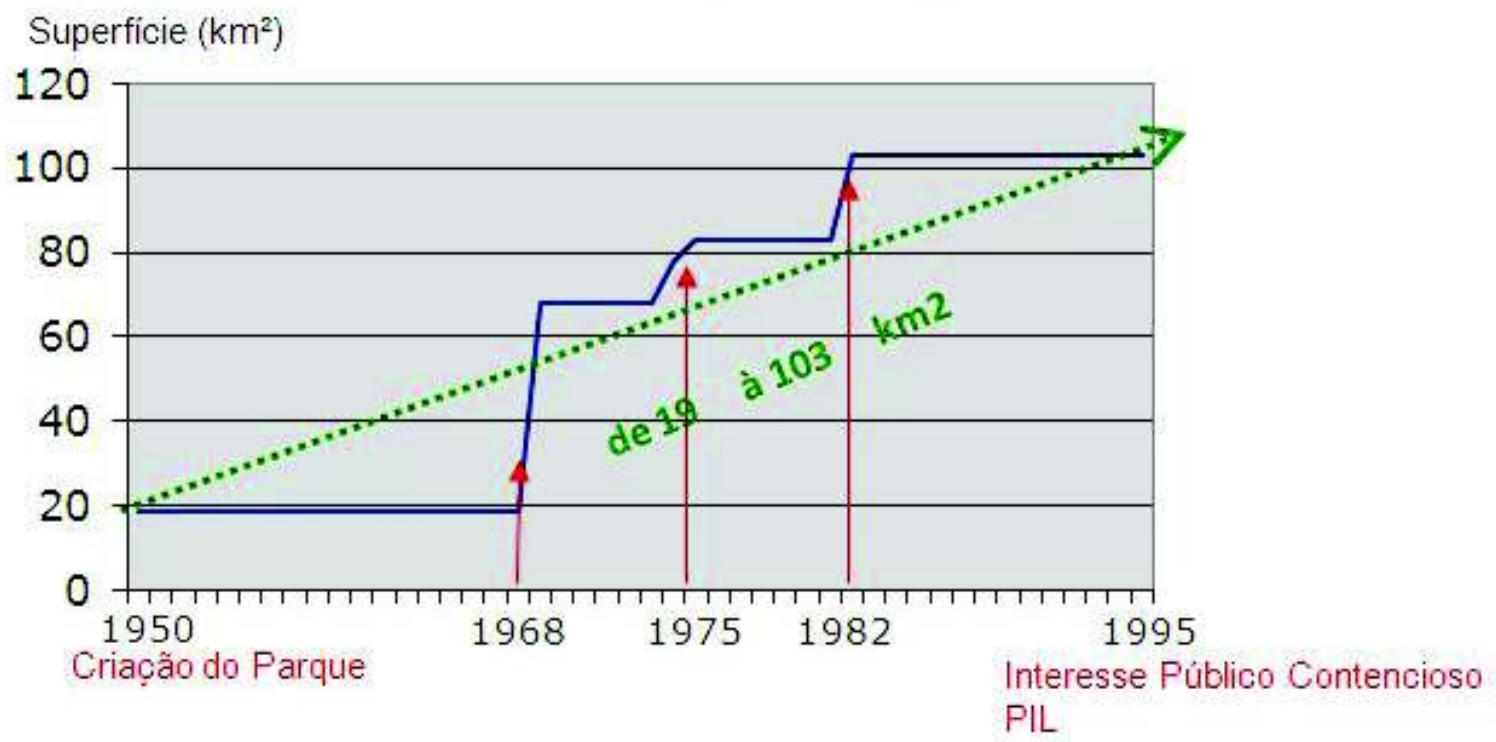

Figura 11 - Gráfico representativo de crescimento do Parque

Da mesma forma, desde a sua criação em 1927, há uma evolução do estatuto jurídico até tornar-se um parque nacional em 1982 e um parque natural e reserva florestal em 1995 (Econet, 1997). O parque abrange vários atos: o Indian Forest Act (1927) que estabelece regras para a regulamentação das florestas e dos animais selvagens e o Wildlife Protection Act (1972), que visa proteger os animais silvestres em seu habitat. Os usos consuntivos e não consuntivos da terra e de recursos sempre coexistiram. Esta configuração ambiental complexa não se refletiu no sistema formal de gestão até 1995, enquanto a governança ambiental de áreas urbanas aumentou com o surgimento de organizações não-governamentais proativas e do poder judiciário.

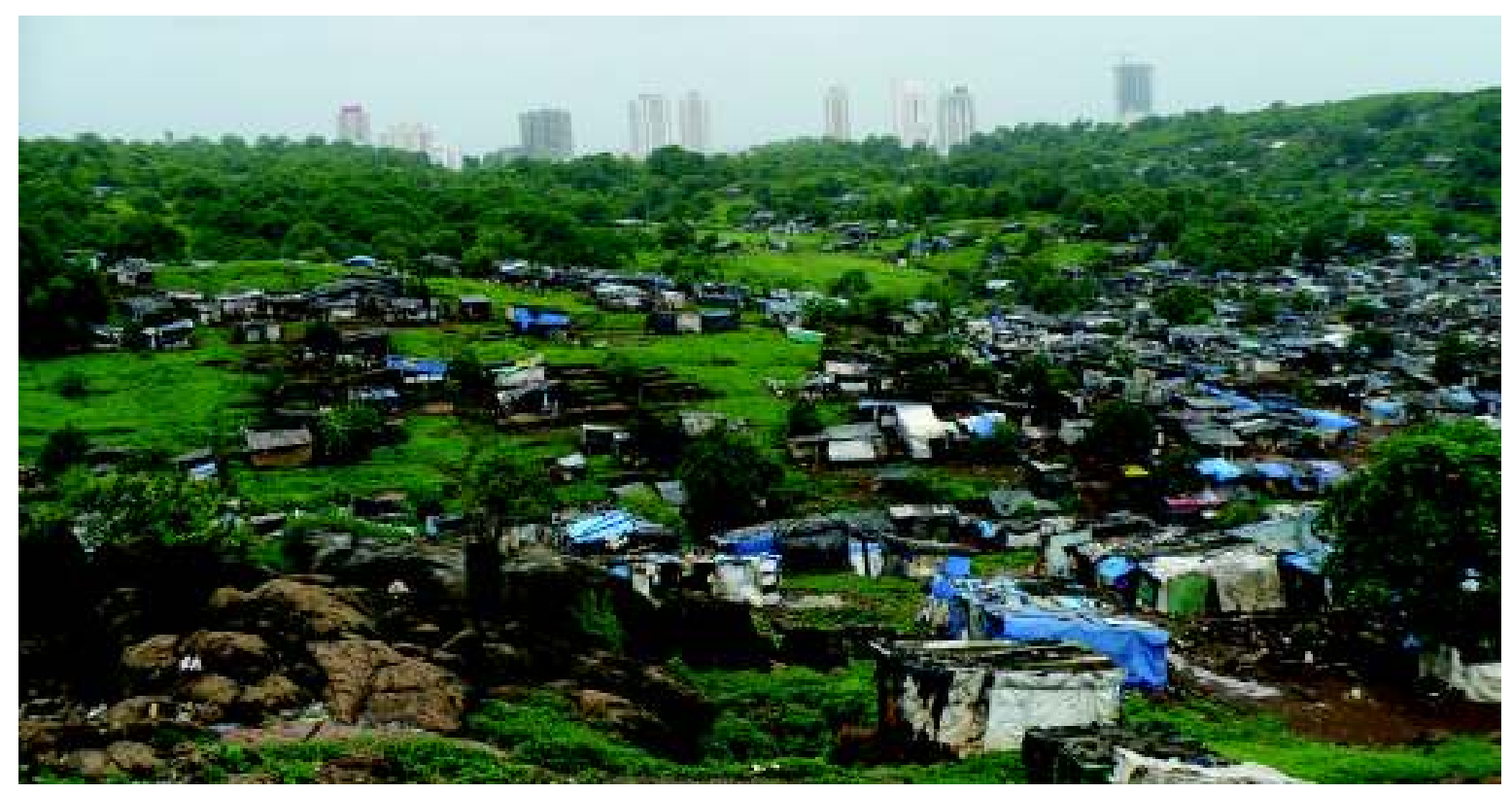

Figura 12 - Moradores dentro do Sanjay Gandhi National Park.

Foto Frédéric Landy, 2009.

Mercator - volume 9, número 20, 2010: set./dez. 
O Parque da Cantareira foi instituído como reserva florestal em 1965 e em 1974 seus administradores elaboraram um Plano de Manejo definindo as estratégias e atividades a serem realizadas. Em 1986 tornou-se um Parque Estadual e em outubro de 1992 foi declarado como integrante da Reserva da Biosfera da Mata Atlântica. Durante 34 anos (até 2008) este plano não foi atualizado, mostrando a desconsideração deste instrumento por sucessivas gestões.

Em 1983 a área do Parque foi tombada por meio da Resolução SC 18/83, de 4/08/1983 do CONDEPHAAT (Conselho de Defesa do Patrimônio Histórico, Arqueológico, Artístico e Turístico do Estado de São Paulo) como Patrimônio do Estado de São Paulo (Silva, Cavalheiro e Kanashiro, 2008). Essa resolução assinala como motivos desse tombamento o grande valor geológico, geomorfológico, hidrológico e paisagístico; a sua condição de banco genético dotado de ecossistemas representativos.

A Reserva da Biosfera do Cinturão Verde (RBCV) abrange uma área de 1.540.032 ha, e incluindo a área urbana, o total de 1.760 .311 hectares, abrangendo o território de 73 municípios e $10 \%$ da população nacional. A RBCV resulta da mobilização social contrário à construção do Rodoanel (trecho norte) que conseguiu juntar 150 mil assinaturas em favor da criação da Reserva e paralisação do Rodoanel. À época o governo do Estado de São Paulo apoiou esse movimento pela conservação ambiental.

No entorno do Parque Estadual da Cantareira as áreas que deveriam constituir as zonas de amortecimento foram destinadas a habitação para parcelas das classes médias e outros setores vêm sendo ocupado ilegalmente por populações de baixíssima renda, especialmente em sua fronteira sudoeste do município de São Paulo. Ao norte, nos municípios limítrofes, especialmente Mairiporã e Caieiras, foram aprovados numerosos condomínios habitacionais de alto padrão. A análise de Koga (2003, p.163) aponta para a situação social de exclusão segundo indicadores de escolaridade, renda e acesso a infra-estrutura, em alguns bairros limítrofes (Pirituba, Brasilândia e Freguesia do Ó são os que apresentam os mais fortes índices de exclusão social). Quanto ao uso do solo, Silva, Cavalheiro e Kanashiro (2008) apontam as modificações ocorridas entre 1962 e 1994 ressaltando a redução da cobertura vegetal natural e da utilização agrícola em favor da área urbana ou de expansão urbana.

\section{Estratégias de políticas e pressão antrópica: o verde se transforma em vantagem imobiliária}

Alguns atores são considerados inimigos comuns pelos conservacionistas. Estes atores não estabelecem uma aliança, mesmo tendo interesses comuns em manter a floresta, Os usos não-florestais são propensos a conflitos abertos com os defensores da proteção, enquanto para os construtores e promotores imobiliários o problema é carência de espaços em Mumbai e São Paulo. Áreas próximas do parque se beneficiam (ou perdem) com o padrão de crescimento urbano de Mumbai e São Paulo, ambos atraídos pela expansão ao "norte". O Parque Sanjay Gandhi está bem perto do centro da aglomeração e o espaço tornou-se cada dia mais atraente. A fim de aliviar a pressão sobre a cidade e os subúrbios próximos ao Parque têm modificado seus zoneamentos, que permitem maiores índices de ocupação dos terrenos.

O mesmo tem ocorrido com o PEC: desde que o verde virou argumento de venda, houve valorização de espaços próximos. A conservação torna-se prioridades para os empreendimentos habitacionais de alto padrão. A especulação imobiliária, e de sua conseqüente exclusão territorial, constitui-se na principal pressão sobre a região do Parque, seja através da divisão de glebas para construção de loteamentos de alto padrão, seja através da expansão de loteamentos em não conformidade com a Lei Federal de parcelamento de solo (Lei 6766/79), tanto no município paulistano como nas demais cidades confrontantes com o Parque Estadual.

Os municípios que fazem limite com o Parque Estadual da Cantareira possuem outro aspecto da degradação potencial: é o aumento do número de casas de veraneio ou a alternativa de fuga dos ambientes urbanos de condomínios de alto padrão, vendidos para a parcela da população de maior poder aquisitivo. Na face norte do Parque, nos municípios de Caieiras e Mairiporã, intensificaram-se 
a pressão antrópica e os conflitos com a política de expansão urbana, apoiada em conjunto pelos municípios e pelo setor imobiliário.

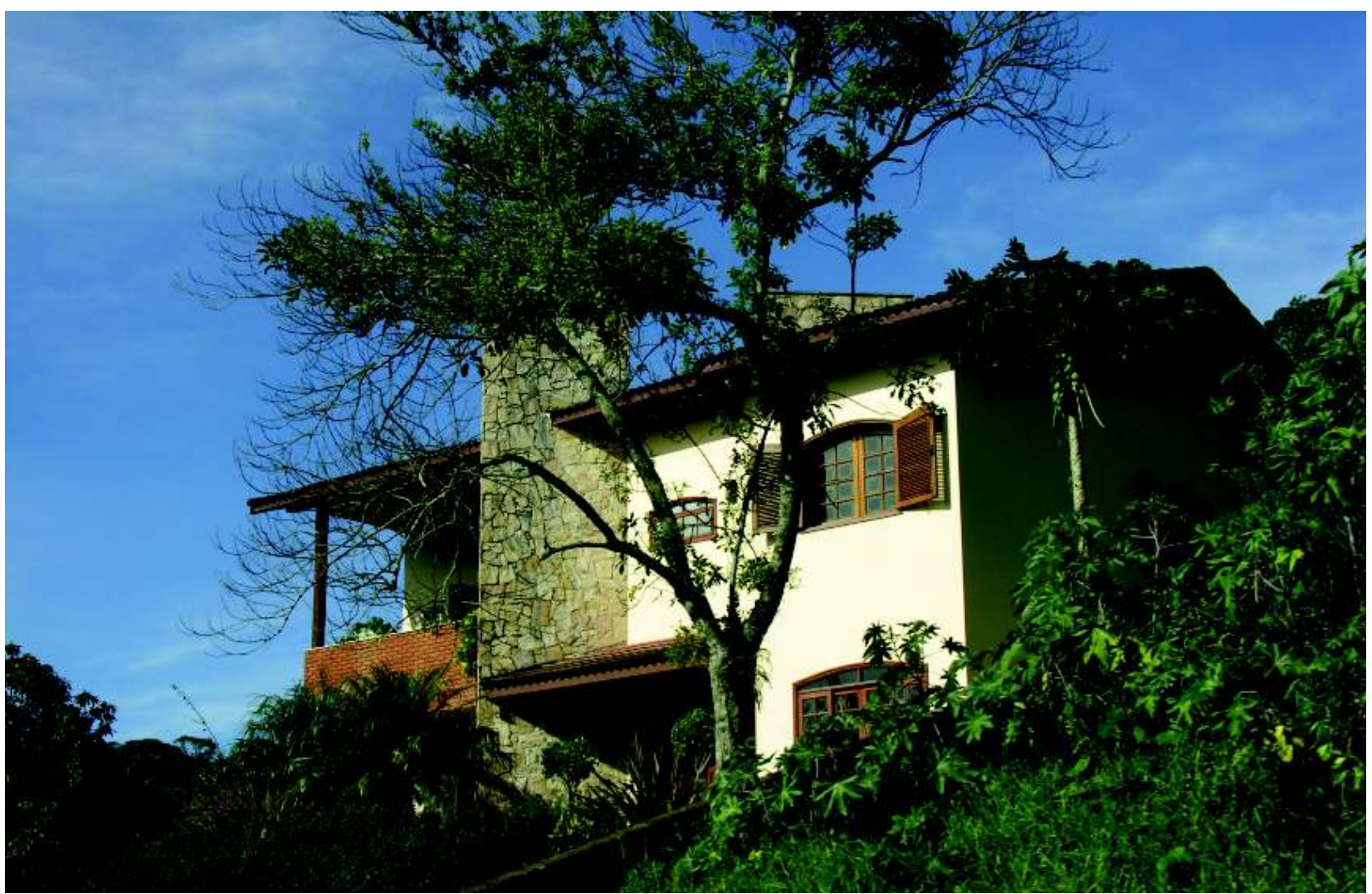

Figura 13 - Condomínios fechados, limítrofes do Parque Estadual da Cantareira, no município de Mairiporã. Foto Hervé Théry, 2007.

\section{CONFLITOS ENTRE CONSERVAÇÃO, OUTROS USOS E RISCOS}

Quanto aos riscos ambientais, estes afetam mais profundamente os moradores de favelas. Os argumentos para remover favelas por conta do risco de desabamento é mais utilizado pelos agentes da defesa civil no Brasil, enquanto o problema de abastecimento de agua é enfatizado em Mumbai.

Para Simanauskas (2008, citando RATHSAM, DARRIGO E PIEDADE, 2004: 420) “(...) os mais pobres tem solucionado o problema de morar predominantemente por meio da aquisição de lotes irregulares ou clandestinos, seguidos da autoconstrução, ou da invasão e favelização de áreas públicas ou privadas", agravando os problemas ambientais, com o despejo dos detritos nas águas dos mananciais diariamente.

A retirada da população das zonas de risco merece reflexão mais aprofundada. A Defesa Civil de São Paulo retira a população que ocupa ilegalmente as áreas íngremes ou zonas de risco de escorregamentos e deslizamentos e lhes oferecia, em 2007, um pagamento de R \$ 5.000,00 (cinco mil reais) por barraco.

A preocupação da Defesa civil é retirá-los dessas zonas. Não há, porém, acompanhamento de onde essas famílias irão se instalar. Nas entrevistas os gestores das subprefeituras apontam que normalmente essas famílias procuram outros lugares tão instáveis quanto os primeiros, muitas vezes na expectativa de novamente vender seu barraco pelo preço estabelecido. Esse modelo de gestão, se de um lado evita o agravamento de problemas nas encostas e evitam até mesmo a possibilidade de mortes, de outro, é um eterno recomeçar, já que as famílias retiradas irão se instalar em áreas similares, provavelmente mais distantes, áreas não passíveis de ocupação, segundo o ordenamento territorial. 
Por outro lado, o argumento ambiental é mais comumente utilizado para proteger os habitantes dos assentamentos formais. Em Mumbai, a ação de Contencioso de Interesse Público (PIL, 1995) proposto por BEAG sublinhou os efeitos "ecologicamente desastroso" das invasões de favelas.

A localização de aglomerados habitacionais em regiões de declividades acentuadas, proximidades de recursos hídricos, e áreas mais susceptíveis a processos erosivos sem o devido planejamento e fiscalização configura-se, assim, como um amplificador processo de vulnerabilidade social inerente a essa dinâmica sócio-ambiental. Amplia-se o potencial de degradação ambiental.

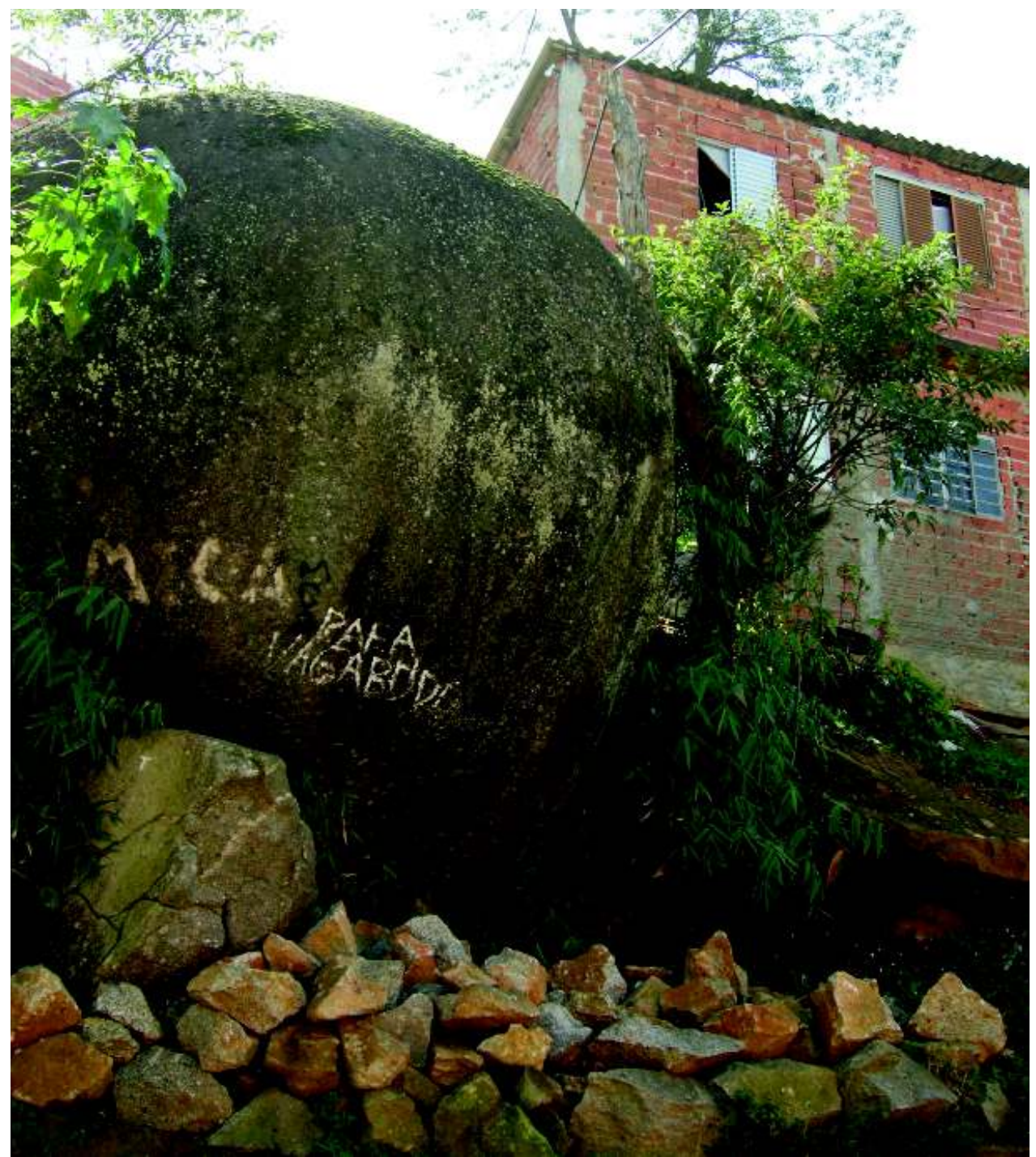

Figura 14 - Moradia no Parque de Taipas, limite noroeste do Parque Estadual da Cantareira. Foto Hervé Théry, 2008.

Ocupar áreas íngremes, retirar a vegetação que sustenta as encostas, substituindo-as por moradias inadequadas, por loteamentos irregulares, é o próprio fator gerador dos escorregamentos e deslizes constantes em períodos chuvosos. Os riscos não se reduzem a apenas serem desalojados. Os custos, não se reduzem aos econômicos. Os mais difíceis de serem mensurados são os sociais e ambientais: população desalojada, vertentes erodidas e rios assoreados que manterão o ciclo vicioso de enchentes e inundações no período chuvoso subseqüente.

O ponto principal é que as instituições de apoio aos sistemas de gestão de recursos, ou seja, direitos de propriedade efetivos, assim como as regras de aplicação de sanções, são necessários para alcançar a gestão sustentável das florestas e da fauna selvagem no longo prazo. As práticas de gestão têm sido mais reativas que pró-ativas. O sistema predominante de gestão e de acompanhamento é, 
de alguma forma, uma hibridização do sistema formal (administrativa) e informal (práticas sociais). Os direitos locais de apropriação informal existem à margem do sistema formal de gestão. É por isso que tanto o reconhecimento das representações sociais e práticas, bem como o reconhecimento de múltiplos interesses e partes interessadas são essenciais para permitir um sistema eficaz de gestão e melhorá-lo em longo prazo. A participação das partes interessadas (dos stakeholders) é condição sine qua non para a viabilidade, eficácia e eficiência da gestão sustentável de parques. Enquanto os gerentes de parques ignorarem e negarem esta realidade, eles serão incapazes de geri-los eficaz e eficientemente.

No caso do SGNP seria mais rentável para a conservação da biodiversidade reconhecer a floresta agrícola situada no parque como ecótono de modo a apoiar evoluções positivas de padrões de cultivo, através de incentivos econômicos, conselhos técnicos e regulamentos, em vez de ignorá-la. A reabilitação in situ das florestas e conservação da vida silvestre com a participação dos moradores da floresta é melhor que expulsa-los sem qualquer alternativa de emprego. Os moradores tribais da floresta podem ser estimulados a aumentar suas coleções para compensar a perda de meios de subsistência. Qualquer tentativa de construir uma parede, uma linha divisória (em concreto), entre natureza e cultura, é a solução mais simplista de se adaptar à natureza complexa do panarchy em sistemas humanos e naturais (Gunderson e Holling, 2002).

Devido a esta complexidade crescente, os conflitos ambientais "e em torno de" áreas protegidas não são raros. Estes conflitos são mais agravados pelo contexto periurbanos do SGNP e do Parque Cantareira. Servindo-nos de uma tipologia dos conflitos ambientais em torno dos Parques identificamos:

a) Conflitos de representações entre o lobby conservacionista e "o resto do mundo" (redes econômicas e sociais) sobre a divisão entre natureza e cultura em nível constitutivo;

b) Os conflitos baseados no direito de propriedade (terra e recursos) entre o lobby conservacionista e "o resto do mundo" sobre o desenvolvimento e ordenamento do território;

c) os conflitos de direitos constitucionais relacionados com o ambiente versus justiça social, que defendem a aplicação do direito, das leis (ainda que sejam leis ambientais contra as leis sociais);

d) Conflitos entre os seres humanos e os predadores selvagens sobre território.

Os conflitos abertos decorrem de não ser possível a convivência de usos, mesmo por um curto período: ou existe uma floresta, ou a floresta é substituída para por outros usos da terra. Assim, ambientalistas e instituições responsáveis pela gestão conflitam com dois tipos de uso da terra no SGNP:

a) Atividades econômicas: há pedreiras em atividade na região metropolitana de Mumbai e em São Paulo, indústrias de exploração de areia, argila, água mineral, granito e gnaisse e numerosos empreendimentos menores, sem regularização. Há um comprometimento de $27 \%$ do território do sistema Cantareira, requerido para a mineração, o que caracteriza o cenário de pressão sobre a área, e, sobretudo sobre o PEC, uma vez que parcela significativa dessas pessoas jurídicas está localizada nos municípios de Mairiporã e São Paulo;

b) Habitação: há 54 assentamentos no interior do parque, incluindo nove padas puramente tribais, atingindo cerca de 60000 pessoas, apesar das expulsões (Mumbai) e em toda zona de amortecimento do PEC há bairros consolidados e em consolidação;

c) Outras atividades: em Mumbai, atividades religiosas (dargahs muçulmano) e a atividade turística (cavernas Kanheri adorada pelos hindus). Conflitos de estratégias territoriais e espacialização das políticas.

Mercator - volume 9, número 20, 2010: set./dez. 
Várias legislações urbanísticas e ambientais ora convergem ora contrapõem-se. As leis de proteção de mananciais (APM) têm sido vistas como impeditivas ao desenvolvimento porque, inviabiliza investimentos em infraestrutura e não garantem a qualidade da água.

De fato, existe um conflito entre a legislação de proteção aos mananciais contemplados e as políticas de expansão praticadas pelos municípios limítrofes ao parque e constituem parte da inconsistência jurídica, pois o município gerencia o uso do solo em seu território, mas os mananciais e recursos hídricos é atribuição do Estado.

Especificamente, no caso do PEC e parte do sistema Cantareira, a possibilidade desse enfoque é pertinente e potencialmente exeqüível, em confrontação com as políticas de expansão urbana dos municípios de seu entorno.

Os conflitos de uso entre conservação e habitação são também analisados por Ross (2004) ao argumentar que há uma forte contradição entre os preceitos preservacionistas e a pressão urbana, notadamente identificados na forte especulação imobiliária presente tanto no sistema Guarapiranga quanto no Sistema Cantareira. Essa especulação, de um lado, e a dificuldade de fiscalização pelos governos, de outro, facilita a ação dos loteadores que burlam a lei e parcelam o solo em lotes localizados em declividades ou outra área interditada para o uso de lotes, cujo tamanho não ultrapassa a $150 \mathrm{~m}^{2}$ e convencem facilmente a população necessitada. Além disso, a pressão da expansão urbana desconsidera os fatores naturais, impondo alterações no meio físico e biótico, além de seus limites de tolerância, modificando seus mecanismos naturais.

Por conta desse uso não permitido e inadequado, há constantes escorregamentos e deslizes nos limites do Parque Estadual, especialmente nas áreas mais íngremes. Ross (2004, p. 213-214) classifica dois ambientes distintos em que ocorrem os deslizamentos induzidos pela ação humana: nas favelas e nos bairros de periferia.

Nas favelas, as habitações precárias estão freqüentemente [...] instaladas em terrenos de altas declividades, $[\ldots]$ em cabeceiras de drenagem em terrenos muito inclinados e úmidos, $[\ldots]$ em aterros (lixo, entulho, madeira usada, resíduos vegetais) mal compactados e mal drenados". [...] nos bairros de periferia geralmente em relevos com vertentes muito inclinadas associadas a habitações auto-construídas [...] em rochas cristalinas e cristalofilianas ou em solos espessos, mas c[...] com características mecânicas de materiais de baixa coesão, permeável e poroso.

Grosso modo, portanto, os limites do Parque Estadual da Cantareira vêm sendo muito pressionado pelo aumento continuo de habitações de baixa renda que avança diária e constantemente, apesar o trabalho continuo de fiscalização que os fiscais do Instituto Florestal promovem. A ocupação das encostas do Parque Estadual da Cantareira nos limites dentro do município de São Paulo e a ocupação por condomínios nos outros municípios é o exemplo mais gritante. Em São Paulo há uma fiscalização cotidiana, mas, é exatamente de onde decorre a pressão para a expansão urbana mais forte e de população de mais baixa renda. Nos outros municípios da fronteira norte do Parque não há restrição de uso ao contrário, há um processo de incentivo à instalação de condomínios residenciais, para população de renda mais elevada.

O primeiro e principal desafio é conciliar as políticas setoriais no interior dos municípios, que se contradizem. Todos os municípios limítrofes a São Paulo têm seu plano diretor e as leis de uso e ocupação do solo como instrumento fundamental para o planejamento e o controle ambiental urbano, articulando-se com as problemáticas do crescimento das cidades e da expansão urbana. Em todos eles, a pressão antrópica é ainda maior do que em São Paulo. A este desafio agregam-se as dificuldades de políticas distintas entre os municípios, na falta de uma articulação maior e mais definitiva dos integrantes da região metropolitana.

Em Mumbai, as estratégias de política também conflitam, senão legalmente, nos mecanismos de operacionalização. Como parceria público-privada é aceita para a reabilitação em Mumbai (Dupont e Saglio, 2009) este pode ser visto como uma grande oportunidade para a coalizão boom 
de construção e a tendência sobre a reabilitação. Uma parte da elite urbana é fortemente suspeita de instrumentar a causa ambiental e a retórica sobre o desenvolvimento sustentável, em nome e no lugar das futuras gerações "para desfrutar de uma boa visão do Parque" (SRINIVASAN, 2004: 6). Em certa medida, a MMRDA apóia esta posição. Sob a presidência do ministro-chefe (Shri Manohar Joshi), o MMRDA incluiu os 103 km ${ }^{2}$ SGNP no plano de desenvolvimento (1996-2011) da Região Metropolitana de Mumbai e classificando-a como "zona de recreação e turismo" em 16 de abril de 1997 sem nenhuma objeção de BEAG (Bombay Grupo de Ação Ambiental) (CHAVAN, 2006: 9). É dupla a principal estratégia das elites urbanas. Por um lado, eles têm empurrado favelados usando PIL e do sistema judiciário para pressionar o SGNP de fora. Também estão trabalhando internamente como consultores oficiais do Departamento Florestal, atuando sobre o Parque. Quer ou não essas elites têm ligações com o verdadeiro boom de construção e podem beneficiar da estratégia pró-activa. Está em jogo o "embelezamento" da cidade de Mumbai. No entanto, outras elites se colocam como ativistas sociais, também usando as ferramentas do Judiciário para ter os direitos "dos pobres" respeitados. Está agenda verde versus marrom das elites urbanas promove ainda mais a fragmentação do espaço urbano em Mumbai (cidade Naivar 2008).

Muitos políticos locais fazem campanha para regularização indiscriminada de invasões e de reabilitação in situ e têm investido durante os períodos eleitorais. Relatou-se que a pressão política impediu a remoção da invasão, bem como a construção do muro de contorno. Junto a estes políticos estão os desenvolvedores que apóiam os moradores de favelas, uma vez que poderão se beneficiar da terra, mais cedo ou mais tarde. Ambos, políticos populistas e desenvolvedores, estão torcendo pela decisão judicial sobre o SGNP.

No caso do SGNP, mesmo os proprietários de terra privada, cuja terra foi adquirida pelo Departamento de Florestas em meados dos anos 70, não receberam as notificações judiciais. Esta lacuna de informação entre a burocracia e as partes interessadas levou a conflitos de direitos de propriedade.

\section{CONSIDERAÇÕES FINAIS}

As ações públicas em prol da conservação ambiental devem considerar múltiplas estratégias. Para que sejam efetivas as políticas habitacionais e que não sejam conflitantes com as ambientais é preciso que a legislação seja cumprida e que a valorização dos elementos conservados não seja somente em decorrência de novas oportunidades imobiliárias.

As diferenças entre as políticas, com objetivos similares identificadas na gestão das unidades de conservação em São Paulo e Mumbai, estão principalmente na forma de operacionalizar a gestão: se no Brasil não há punição com alterações no uso de uma unidade de conservação, permitindo que o antropismo esteja cada dia mais intenso nas zonas de amortecimento e no interior do Parque Estadual da Cantareira; em Mumbai grupos ativistas junto com gestores promovem forte fiscalização para que se cumpra a legislação privilegiando as remoções. De maneira semelhante concluiu-se que para garantir a legitimidade das políticas publicas espaciais (ambientais e habitacionais) é fundamental a presença da sociedade organizada e mesmo das comunidades (vizinhas ou internas) às unidades de conservação.

Um conflito é baseado em uma relação entre tempo e lugar como nos lembra Charlier (1999, citado por Laslaz, 2007). As forças na luta pelo poder agem ao mesmo tempo e no mesmo lugar para um conflito a se tornar aberto. O conflito pode permanecer em estado latente, se o local é o mesmo, mas não o tempo. No caso SGNP, o conflito ocorreu desde quando o "lado social" reagiu com força no mesmo "espaço-temporal" que as forças ambientais. Antes de 1995 aconteceram pequenos conflitos, após 2002, a polêmica acirrou-se, mas o lançamento da colônia de reassentamento em Chandivali permitiu diminuir a escala de intensidade de conflitos: isso mostra que, embora os conflitos possam ser classificados em função da sua intensidade, raramente é uma evolução contínua e linear. Há, antes, uma sobreposição de vários sub-conflitos. 
O aumento de fragilidade ambiental está conduzindo a mais e mais medidas drásticas para proteger áreas de biodiversidade, pois há mais interesse em compreender as complexas inter-relações entre as cidades e os ecossistemas de maior dimensão (Trzyna, 2007). Mas as florestas urbanas são resquícios em apuros, consideradas "em um mar de concreto urbano, pois é um refúgio à distância para as populações urbanas» (TRZYNA, 2005, p.7). Os atores globais se posicionam: o Banco Mundial, que é tão ativo no setor de transporte urbano, não intervém. Em São Paulo, no PEC a UNESCO é um ator importante, atuando com monitores oriundos das comunidades adjacentes.

$\mathrm{Na}$ Índia, as áreas protegidas têm aumentado nas últimas décadas. Dois processos são desenvolvidos simultaneamente: desde a década de 1970 torna-se mais comum o uso de Interesse Público Contencioso (PIL), e o crescimento da classe média (e não uma elite social) com os valores ambientais algumas vezes baseado no nacionalismo hindu (MAWDSLEY, 2006); em 1997, a Suprema Corte da Índia aprovou a decisão que exigiu de todos os serviços florestais no país a resolução no prazo de um ano, dos direitos existentes nas áreas protegidas indianas. Isso se traduziu em remoção das populações dentro de Parques Nacionais e reduziu o acesso aos recursos para aqueles que vivem em santuários da vida selvagem ou em áreas adjacentes das áreas protegidas. Este acórdão do Supremo Tribunal é incontestável, gerando impacto direto sobre o SGNP com o lançamento de um PIL em 1995 para expulsar invasores.

A expansão urbana, por si só não é um fator de crescente conscientização quanto à necessidade de proteger o parque. No entanto é um processo fundamental que explica o aumento da pressão sobre áreas florestais devido à escassez de espaço urbanizável. Mas parece difícil supor que existe uma relação linear entre a magnitude da expansão urbana e do aumento da controvérsia sobre o SGNP. Mais de 10 anos após o alargamento do Parque para $103 \mathrm{~km}^{2}$ e do surgimento das favelas a disputa terminou.

Em ambos os Parques, as políticas, os conflitos de uso e a pressão antrópica são de características e intensidades semelhantes; é no aspecto de gestão que os mesmos se diferenciam.

\section{REFERÊNCIA BIBLIOGRÁFICA}

BIEDERMAn, Ciro; MEYER, Regina Maria; GROSTEIN, Marta Dora. São Paulo Metrópole. São Paulo: EDUSP, 2004.

BON, Emanuel, LANDY, Frédéric et al. Stakes, Actors and Strategies "In and Around" Mumbai's Urban Forests. The case of the Sanjay Gandhi National Park. Territorial integration and exclusion. Impact of urban policies and law. New Delhi: CSH-India International Centre, 2008.

BONDUKI, Nabil. Origens da Habitação Social no Brasil: arquitetura moderna, lei do inquilinato e difusão da casa própria. São Paulo: Estação Liberdade, 2004.

CHAVAN, Vidya, Krishnagiri to Sanjay Gandhi National Park, Ghar Hakka Jagruti Parishad. Mumbai: 2007.

DUPONT Veronique, SAGLIO-YATZIMIRSKY Marie-Caroline. Programas de erradicação, reassentamento e urbanização das favelas: Delhi e Mumbai. Revista dos Estudos Avançados, São Paulo, Vol. 23, No 66, pp. 283-302, 2009.

ECONET (Mumbai, Maharasthra). A comprehensive environmental assessment of SGNP (Borivili National Park), Study Commissioned by the Maharashtra State Division of the WWF. Mumbai. World Wild Life Fund: 1997, 129 p.

GUNDERSON, L. H. e HOLLING, C. S. (eds). Panarchy: Understanding Transformations in Human and Natural Systems. Washington, D.C.: Island Press. 2002.

INTERNATIONAL UNION CONSERVATION OF NATURE. Workshop on Cities, Ecosystems and Biodiversity, Kenya Wildlife National Headquarters. Task Force on Cities and Protected Areas, WCPA/ IUCN, http://www.InterEnvironment.org/pa. 2006

KOGA, Dirce. Medidas de cidades: entre territórios de vida e territórios vividos. São Paulo: Cortez. 2003. 
PARANJPYE, V., ECONET, A comprehensive environmental assessment of SGNP (Borivili National Park), Mumbai, Study Commissioned by the Maharashtra State Division of the WWF. Mumbai, World Wild Life Fund, 1997, 129 p.

RATHSAM, Luciana Araico; DARRIGO, Márcia; PIEDADE, Mônica Amaral. Habitação de Interesse Social e Impactos Ambientais. In ROMÉRO, Marcelo de Andrade; PHILIPPI, Arlindo Jr.; BRUNA, Gilda Collet (Ed.). Panorama ambiental da Metrópole de São Paulo. Coleção Estudos e Pesquisas Ambientais. Signus Editora. São Paulo, 2004

ROLNIK, Raquel, SAULE JUNIOR, Nelson. Habitat II- assentamentos humanos como tema global. In: Bonduk, Nabil. Habitat - as práticas bem sucedidas em habitação, meio ambiente e gestão urbana nas cidades brasileiras. 2a . Ed. São Paulo: Studio Nobel, 1997.

ROSS, Jurandyr L. São Paulo: a cidade e as águas. In: Ana Fani Alesandri Carlos e Ariovaldo Umbelino de Oliveira. (Org.). Geografias de São Paulo - A Metrópole do Séc. XXI. 1 ed. : , 2004, v. 2, p. $183-220$.

SACHAR, R., SURESH, H., DAUD, S. M. Crushed homes, lost lives: The story of the demolitions in Sanjay Gandhi National Park. The Indian Peoples Human Rights Tribunal on Sanjay Gandhi National Park. The Indian Peoples Human Rights Commission. Mumbai: 2000. 68 p.

SARTORI, Giovanni. A política. Ed. Universidade de Brasília, 1981.

SARAIVA, Camila; MARQUES, Eduardo. A condição social dos habitantes de Favelas. In: Marques, Eduardo; Torres, Haroldo. (Org.). São Paulo: segregação, pobreza urbana e desigualdades sociais. São Paulo: Senac, 2005. p.143-167.

SIMANAUSKAS, Lívia. Planejamento urbano e conservação de florestas periurbanas: um estudo de caso sobre a zona de amortecimento da ocupação sul do Parque Estadual da Cantareira. Monografia de iniciação científica. PIBIC/EACH/USP. Junho de 2008

SILVA, Lucia Sousa e GROSTEIN, Marta D. Proteção ambiental e expansão urbana: a ocupação do sul do Parque Estadual da Cantareira. IN GROSTEIN, Marta D. (org). Ciência ambiental. Questões e métodos. São Paulo: FAPESP/Annablume, 2008.

SILVA, Dimas Antônio CAVALHEIRO, Felisberto e KANASHIRO, Marina Mitsue. Evolução do uso e ocupação da terra no entorno dos Parques Estaduais da Cantareira e Alberto Löfgren. I Fórum de Debates. Ecologia da paisagem e planejamento ambiental. http://www.seb-ecologia.org.br/forum/art30.htm. (consultado em 03.setembro.2008)

SRINIVASAN, K. Sanjay Gandhi National Park: Justice for Whom, Justice for What? Draft paper, Department: Urban and Rural Community Development (?). 2004.

WEINSTEIN, Liza. Mumbai's Development Mafias: Globalization, Organized Crime and Land Development. International Journal of Urban and Regional Research v. 32, p. 22-39. 2008.

ZERAH, Marie-Hélène. Conflict between green space preservation and housing needs: The case of the Sanjay Gandhi National Park in Mumbai. Cities, v. 24(2), p.122-132. 2007.

Trabalho enviado em setembro de 2010

Trabalho aceito em dezembro de 2010

Mercator - volume 9, número 20, 2010: set./dez. 